\title{
ANALISIS PEMANFAATAN PERPUSTAKAAN SEKOLAH TERHADAP PRESTASI BELA- JAR SISWA KELAS V SD NEGERI NGABLAK 1 KECAMATAN NGABLAK KABUPATEN MAGELANG
}

Istiqomah

Sekolah Dasar Negeri Ngablak 1 Magelang

Email : istisuryono@gmail.com

\begin{abstract}
Abstrak
Prestasi belajar adalah output dari proses belajar siswa di Sekolah. Proses belajar dapat dilakukan juga di Perpustakaan Sekolah. Siswa dapat memanfaatkan perpustakaan dengan berkunjung dan membaca buku di Perpustakaan ataupun sekedar meminjam buku. Penelitian mengenai pengaruh pemanfaatan perpustakaan terhadap prestasi belajar siswa perlu dilakukan. Penelitian ini menggunakan metode observasi, dokumentasi dan menggunakan analisis kualitatif. Metode observasi digunakan untuk mengetahui siswa dalam mengunjungi dan meminjam buku dalam pemanfaatan perpustakaan sekolah. Metode dokumentasi digunakan untuk mengetahui hasil dari prestasi belajar siswa. Sedangkan analisis kualitatif digunakan untuk mengetahui bagaimana pengaruh pemanfaatan perpustakaan sekolah terhadap prestasi belajar siswa. Objek penelitian ini adalah siswa kelas V SD Negeri Ngablak 1 Kecamatan Ngablak Kabupaten Magelang tahun 2019. Hasil penelitian menunjukan, jumlah kunjungan ke perpustakaan siswa kelas V pada semester 2 tahun 2019 sebanyak 1946 kali dan peminjaman sebanyak 717 kali. Pemanfaatan frekuensi berkunjung dan peminjaman terbanyak adalah GN, AN, GE dan US dengan rangking prestasi berurutan yaitu rangking 1, 2, 3 dan 4. Pengaruh frekuensi berkunjung dan meminjam di perpustakaan berpengaruh pada prestasi belajar Tes Akhir semester 2 tahun 2019 di sebagian besar siswa kelas V SD Negeri Ngablak 1. Siswa dengan frekuensi kunjungan dan peminjaman ke perpustakaan lebih sedikit juga sebagian memiliki prestasi yang lebih rendah.
\end{abstract}

\section{Kata kunci :}

Pemanfaatan Perpustakaan,

Prestasi Belajar,

Perpustakaan.

\section{A. PENDAHULUAN}

Pendidikan adalah sarana yang penting dalam memajukan dan mencerdaskan kehidupan bangsa Indonesia, salah satunya cara dalam memperoleh Pendidikan yaitu melalui Pendidikan formal. Pendidikan formal adalah Pendidikan yang dilaksanakan di lingkungan sekolah. Dalam melaksanakan Pendidikan formal di Sekolah, ada beberapa faktor yang terlibat yaitu guru sebagai pengajar, siswa, materi pelajaran dan fasilitas penunjang dalam belajar. Pendidikan di Sekolah dituntut untuk menghasilkan Sumber Daya Manusia (SDM) yang unggul dan berkualitas. Untuk memenuhi tuntutan tersebut salah satunya upaya yang dapat dilakukan yaitu dengan menyediakan fasilitas penunjang yaitu berupa Perpustakaan Sekolah.

Prestasi belajar adalah hasil dari proses kegiatan belajar mengajar siswa di Sekolah melalui evaluasi belajar yaitu dimulai dari ulangan, tes tengah semester, tes akhir semester dan tes akhir sekolah (UAN/ UAS). Prestasi belajar sebagai ukuran keberhasilan siswa dan pengajar dalam kegiatan belajar mengajar (KBM). Pengajar yaitu guru menggunakan prestasi belajar sebagai ukuran keberhasilan metode pembelajaran yang dilakukan guru. Bagi siswa, prestasi belajar sebagai ukuran keberhasilan siswa dalam memahami dan mengukur kemampuan belajarnya. Selain kegiatan belajar mengajar dilakukan di dalam kelas, siswa juga dapat memperoleh pengetahuan dan ilmu tambahan melalui pembelajaran diluar jam pelajaran yaitu melalui memanfaatkan fasilitas perpustakaan.

Menurut Ibrahim Bafadal :

"perpustakaan sekolah tampak bermanfaat apabila benar - benar memperlancar pencapaian tujuan proses belajar mengajar di Sekolah. Indikasi manfaat tersebut tidak hanya tingginya prestasi siswa, tetapi lebih pada ketika siswa mampu mencari, menemukan, menyaring 
Analisis Pemanfaatan Perpustakaan Sekolah Terhadap Prestasi Belajar Siswa Kelas V SD Negeri Ngablak 1 Kecamatan Ngablak ...

Istigoma

dan menilai informasi, belajar secara mandiri, mengikuti perkembangan ilmu pengetahuan dan teknologi dan lainnya." (Bafadal, 2006)

Perpustakaan SD Negeri Ngablak 1 Kecamatan Ngablak Kabupaten Magelang terletak di depan pintu masuk sekolah dan juga disamping ruang guru, sehingga mudah dijangkau, memiliki tenaga pustakawan yang sesuai dengan bidangnya dan diikuti dengan pelayanan yang optimal. Meskipun tergolong baru dibangun beberapa tahun ini, perpustakaan inijuga memiliki tempat yang nyaman dan dilengkapi dengan berbagai buku sebagai bahan belajar siswa. Setiap tahunnya perpustakaan di sekolah ini juga mendapat tambahan buku dari Bantuan Operasional Sekolah, dan juga donasi dari guru dan murid di sekolah tersebut. Perpustakaan di SD Negeri Ngablak 1 ini memiliki koleksi buku sebanyak 3.220 eksemplar.

Berdasarkan hasil data pengunjung dan daftar peminjaman buku perpustakaan, antusias siswa dalam memanfaatkan perpustakaan sekolah ternyata cukup tinggi. Siswa datang mengunjungi perpustakaan sekolah ketika jam sekolah sedang istirahat dan juga ketika ada tugas khusus dari Guru. Pemanfaatan perpustakaan sekolah diharapkan mampu untuk menunjang prestasi belajar siswa karena disediakan berbagai buku yang bermutu.

Berdasarkan data yang dihimpun penulis, penulis mengidentifikasi permasalahan dalam penelitian ini yaitu: Bagaimana Pengaruh Pemanfaatan Perpustakaan terhadap Prestasi Belajar Siswa Kelas V SD Negeri Ngablak 1 Kecamatan Ngablak Kabupaten Magelang?

\section{B. KAJIAN TEORITIS}

Graham R. Daniel, Cen Wang dan Donna Berthelsen menjelaskan keterlibatan orang tua diterima secara luas karena dikaitkan dengan peningkatan hasil pendidikan anak-anak (R et al., 2016). Namun, peran keterlibatan orang tua berbasis sekolah awal masih ditetapkan. Penelitian ini menyelidiki peran mediasi dari perilaku belajar yang diatur sendiri dalam hubungan antara keterlibatan orang tua berbasis sekolah awal dan prestasi akademik anak-anak, menggunakan data dari Longitudinal Study of Australian Children ( $N=2616)$. Posisi sosial ekonomi keluarga, status Aborigin dan Torres Strait Islander, latar belakang bahasa, jenis kelamin anak dan kompetensi kognitif, dikendalikan, serta aktivitas keterlibatan orang tua berbasis rumah dan masyarakat untuk mendapatkan interpretasi yang lebih percaya diri dari hasil. Analisis pemodelan persamaan struktural menunjukkan bahwa perilaku belajar yang diatur sendiri oleh anak-anak sepenuhnya memediasi hubungan antara keterlibatan orang tua berbasis sekolah di Kelas 1 dan prestasi membaca anak-anak di Kelas 3. Yang penting, hubungan ini terbukti untuk anak-anak di semua latar belakang sosial ekonomi. Meskipun tidak ada hubungan langsung antara keterlibatan orang tua di kelas 1 dan prestasi belajar di kelas 3, keterlibatan orang tua secara tidak langsung dan latar belakang ekonomi terkait dengan pencapaian angka anak yang lebih tinggi melalui pengaturan perilaku belajar anak, meskipun hubungan ini lebih kuat untuk anak-anak dari sosial menengah dan sekolah tinggi. Studi ini mengidentifikasi hubungan positif antara keterlibatan orang tua berbasis sekolah dan siswa pada tahun-tahun awal sekolah, peran perpustakaan dalam memediasi hubungan antara keterlibatan orang tua berbasis sekolah dan prestasi membaca dan berhitung siswa. Asosiasi-asosiasi antara keterlibatan orang tua ini membutuhkan penelitian lebih lanjut tentang bagaimana keterlibatan orang tua berkontribusi pada pengembangan anak dan keterlibatan anak-anak berikutnya di sekolah dan prestasi sekolah mereka selama tahun-tahun sekolah. Temuan ini berkontribusi pada pemahaman yang lebih kompleks dan bernuansa tentang peran keterlibatan orang tua 
dan kemitraan keluarga-sekolah dalam pencapaian anak-anak di sekolah.

Matthew L. Bernacki, Jeffrey A. Greene dan Helen Crompton menjelaskan, bahwa pembelajaran seluler - penggunaan perangkat elektronik pribadi untuk terlibat dalam pembelajaran di berbagai konteks melalui koneksi ke media, pendidik, sejawat, pakar, dan dunia yang lebih besar - adalah perusahaan akademis yang relatif baru (Bernacki et al., 2020). Dalam edisi khusus ini, kami menginterogasi janji dan harapan yang belum diteliti tentang pembelajaran bergerak, teori dan ide yang berkembang di sekitarnya, dan perangkat yang membelinya. Artikel-artikel tersebut memperkenalkan teknologi mobile dan wearable sebagai komponen utama penelitian empiris dan menunjukkan cara pembelajaran yang dilakukan dengan perangkat tersebut (1) memengaruhi proses dan produk pembelajaran melalui interaksi dengan konstruksi psikologis lainnya; (2) memberi peluang baru untuk secara langsung memengaruhi proses atau hasil pembelajaran; dan (3) memberikan peluang untuk mengumpulkan data yang sebelumnya tidak dapat diperoleh yang meningkatkan pemahaman dan pemodelan proses pembelajaran. Dalam pengantar ini, kami meninjau kemunculan teori pembelajaran seluler dan konseptualisasi kontemporernya. Kemudian kami menyoroti cara teknologi seluler dapat digunakan untuk meningkatkan proses pembelajaran dan pemahaman mereka. Semua kontributor edisi khusus mengkonseptualisasikan dan menyelaraskan pekerjaan mereka dengan teori-teori pembelajaran dan pengajaran psikologis serta teori-teori baru tentang pembelajaran bergerak. Penulis komentar menilai penelitian pembelajaran seluler secara kritis dan analitis, dan merekomendasikan cara teori pembelajaran seluler dapat membangun metodologi penelitian dan pengetahuan yang didasarkan secara empiris dalam teori pembelajaran psikologis dan sosiokultural. Secara keseluruhan, kami percaya masalah khusus ini mencapai tujuan kami untuk menghasilkan pertimbangan yang seimbang yang menyoroti kemajuan dalam pembelajaran dan teori belajar yang mungkin dimiliki perangkat seluler, dan untuk meredam antusiasme prematur tentang manfaat potensial ini.

\section{METODE PENELITIAN}

Penelitian dilaksanakan di Perpustakaan SD Negeri Ngablak 1 Kecamatan Ngablak Kabupaten Magelang. Pengumpulan data dimulai tanggal 3 januari 2019 sampai 31 Juni 2019. data yang diperoleh dikelola pada tanggal 24 Oktober 2019. Nilai hasil pelajaran siswa dapat diketahui pada tanggal 31 Juni 2019 yaitu nilai akhir semester dari kelas V SD Negeri Ngablak 1 Kecamatan Ngablak Kabupaten Magelang.

Metode penelitian yang digunakan peneliti yaitu metode penelitian deskriptif, yaitu dengan langkah - langkah sebagai berikut :

1. Metode Observasi (Pengamatan)

"Metode observasi atau pengamatan adalah metode pengumpulan data di mana peneliti atau kolaboratornya mencatat informasi sebagaimana yang mereka saksikan selama penelitian." (Gulo, 2002)

Penelitian tersebut bisa dirasakan, dilihat, didengar yang kemudian dapat dicatat seobjektif mungkin. Peneliti mengumpulkan data dengan mengobservasi melalui daftar siswa SD Negeri Ngablak 1 Kecamatan Ngablak Kabupaten Magelang yang berkunjung ke perpustakaan sekolah selama kurun waktu 6 bulan.

2. Metode Dokumentasi

"dokumen adalah catatan tertulis tentang berbagai kegiatan atau peristiwa pada waktu yang lalu" (Gulo, 2002)

Peneliti menggunakan nilai rapot berbagai pelajaran dari siswa kelas $\mathrm{V}$ sebagai acuan 
prestasi belajar masing - masing siswa. Nilai tersebut diambil rata - ratanya sehingga ditemukan nilai rata - rata dari masing masing siswa.

3. Metode Analisis Data Kualitatif

'Metode Analisis Data Kualitatif merupakan penelitian yang berhubungan dengan data non numeric, dalam mendeskripsikan prosedur prosedur sering menggunakan narasi. Sebagian tidak menggunakan metode statistik dalam membuat kesimpulan, Analisa data hanya menggunakan statistika deskriptif" (Hartinah, 2013)

Penulis akan menganalisis antara pemanfaatan perpustakaan terhadap prestasi belajar siswa dengan menggunakan data - dari dari observasi dan dokumentasi yang disimpulkan dengan metode statistika deskriptif.

\section{HASIL DAN PEMBAHASAN}

\section{Kunjungan dan peminjaman buku kelas V}

Siswa Kelas VSD Negeri Ngablak 1 berjumlah 23 siswa. Perpustakaan SD Negeri Ngablak satu dapat dikunjungi oleh seluruh siswa, namun terdapat penjatahan peminjaman dan pengembalian buku pada siswa setiap harinya supaya pelayanan kepada siswa dapat lebih efektif dan merata. Setiap Senin dan kamis kelas VI dan kelas I, hari selasa dan jumat kelas V dan kelas II, hari rabu dan sabtu kelas III dan kelas IV. Sehingga dapat diketahui data yang diolah tanggal 7 November 2019 setelah terjadi kenaikan kelas bulan Juni, dapat ditemukan data sebagai berikut:

Tabel 1. Jumlah Hari Efektif SD Negeri Ngablak 1

\begin{tabular}{|c|c|c|c|c|c|c|c|}
\hline Hari & Jan & Feb & Mar & Apr & Mei & Jun & \multirow{3}{*}{$\begin{array}{c}\text { Jumlah } \\
\text { Total }\end{array}$} \\
\hline Hari Kalender & 31 & 28 & 31 & 30 & 31 & 30 & \\
\hline $\begin{array}{l}\text { Hari Minggu/ } \\
\text { Libur }\end{array}$ & 5 & 5 & 5 & 12 & 14 & 17 & \\
\hline
\end{tabular}

\begin{tabular}{|l|c|c|c|c|c|c|c|}
\hline $\begin{array}{l}\text { Jumlah Hari } \\
\text { Kunjungan } \\
\text { Efektif }\end{array}$ & 26 & 23 & 26 & 18 & 17 & 13 & 123 \\
\hline $\begin{array}{l}\text { Jumlah } \\
\text { Hari Efektif } \\
\begin{array}{l}\text { Peminjaman } \\
\text { (Selasa dan } \\
\text { jumat) }\end{array}\end{array}$ & 8 & 7 & 8 & 6 & 5 & 4 & 38 \\
\hline
\end{tabular}

Sumber : kalender pendidikan SD Ngablak 1 Kecamatan Ngablak Kabupaten Magelang, 2019

Data mengenai kunjungan siswa ke Perpustakaan Sekolah SD Negeri Ngablak 1 dapat diketahui melalui Tabel 1 . Berdasarkan Tabel 1 diatas dapat diketahui masing - masing kunjungan para siswa kelas $\mathrm{V}$ yang ternyata berbeda - beda,. Siswa yang paling sering berkunjung adalah GE dan AN yang memiliki frekuensi berkunjung yang sama yaitu sebanyak 102 kali, diikuti oleh US dan KR yang frekuensi berkunjung yang sama yaitu 100 kali. Sedangkan frekuensi yang paling jarang berkunjung yaitu DA 64 kali, diikuti NR 67 kali, AJ 70 kali dan HR yang frekuensi berkunjungnya 72 kali.

Tabel 2. Jumlah Kunjungan Perpustakaan siswa Kelas V SD Negeri Ngablak 1

\begin{tabular}{|c|c|c|c|c|c|c|c|c|}
\hline \multirow{3}{*}{$\begin{array}{c}\text { No } \\
\text { Absen }\end{array}$} & \multirow{3}{*}{$\begin{array}{l}\text { Inisial } \\
\text { Nama }\end{array}$} & \multicolumn{6}{|c|}{ Kunjungan } & \multirow{3}{*}{ Jumlah } \\
\hline & & jan & Feb & Mar & Apr & mei & jun & \\
\hline & & 26 & 23 & 26 & 18 & 17 & 13 & \\
\hline 1 & KD & 18 & 19 & 15 & 12 & 9 & 8 & 81 \\
\hline 2 & DA & 15 & 11 & 18 & 8 & 7 & 5 & 64 \\
\hline 3 & MM & 17 & 15 & 21 & 11 & 13 & 9 & 86 \\
\hline 4 & ES & 19 & 17 & 22 & 15 & 12 & 11 & 96 \\
\hline 5 & $\mathrm{GN}$ & 20 & 18 & 23 & 15 & 14 & 12 & 102 \\
\hline 6 & FM & 13 & 17 & 12 & 11 & 13 & 8 & 74 \\
\hline 7 & FA & 14 & 12 & 16 & 9 & 14 & 11 & 76 \\
\hline 8 & $\mathrm{GE}$ & 20 & 18 & 23 & 15 & 14 & 12 & 102 \\
\hline 9 & NR & 14 & 12 & 17 & 12 & 5 & 7 & 67 \\
\hline 10 & $A C$ & 18 & 16 & 14 & 15 & 15 & 10 & 88 \\
\hline 11 & FA & 18 & 20 & 18 & 13 & 11 & 12 & 92 \\
\hline 12 & DS & 20 & 17 & 22 & 12 & 14 & 11 & 96 \\
\hline 13 & LF & 19 & 16 & 22 & 13 & 13 & 11 & 94 \\
\hline 14 & PD & 16 & 11 & 16 & 9 & 12 & 9 & 73 \\
\hline 15 & US & 21 & 19 & 22 & 13 & 14 & 11 & 100 \\
\hline 16 & PDM & 14 & 16 & 18 & 11 & 9 & 11 & 79 \\
\hline 17 & AJ & 17 & 12 & 16 & 12 & 5 & 8 & 70 \\
\hline
\end{tabular}




\begin{tabular}{|c|l|c|c|c|c|c|c|c|}
\hline 18 & KR & 22 & 19 & 20 & 13 & 15 & 11 & 100 \\
\hline 19 & HR & 15 & 17 & 19 & 9 & 5 & 7 & 72 \\
\hline 20 & AN & 22 & 19 & 21 & 14 & 15 & 11 & 102 \\
\hline 21 & GK & 16 & 19 & 15 & 12 & 11 & 6 & 79 \\
\hline 22 & RO & 18 & 12 & 17 & 11 & 9 & 8 & 75 \\
\hline 23 & AY & 18 & 15 & 19 & 11 & 9 & 6 & 78 \\
\hline
\end{tabular}

Sumber : Buku Daftar Pengunjung ke Perpustakaan SD Negeri Ngablak 1

Tabel 2 menunjukan bahwa terdapat frekuensi peminjam koleksi perpustakaan paling sering yang sama yaitu pada siswa ES, GN, GE, DS, LF, PD, US, KR, dan AN yaitu masing-masing sebanyak 38 kali. Sedangkan siswa yang paling sedikit meminjam buku adalah $\mathrm{RQ}$ yang memiliki frekuensi peminjaman 25 kali, diikuti oleh GK dan AY yang memiliki frekuensi peminjaman masingmasing 26 kali.

Tabel 3. Jumlah Peminjaman Koleksi Perpustakaan SD Negeri Ngablak 1 Kec. Ngablak

\begin{tabular}{|c|c|c|c|c|c|c|c|c|}
\hline \multirow{3}{*}{$\begin{array}{c}\text { No } \\
\text { Absen }\end{array}$} & \multirow{3}{*}{$\begin{array}{l}\text { Inisial } \\
\text { Nama }\end{array}$} & \multicolumn{6}{|c|}{ Peminjaman } & \multirow{3}{*}{ Jumlah } \\
\hline & & jan & feb & mar & apr & Mei & jun & \\
\hline & & 8 & 7 & 8 & 6 & 5 & 4 & \\
\hline 1 & $\mathrm{KD}$ & 7 & 5 & 7 & 6 & 5 & 4 & 34 \\
\hline 2 & DA & 6 & 5 & 6 & 3 & 4 & 3 & 27 \\
\hline 3 & MM & 5 & 5 & 6 & 4 & 3 & 4 & 27 \\
\hline 4 & ES & 8 & 7 & 8 & 6 & 5 & 4 & 38 \\
\hline 5 & GN & 8 & 7 & 8 & 6 & 5 & 4 & 38 \\
\hline 6 & $F M$ & 6 & 4 & 4 & 3 & 4 & 3 & 24 \\
\hline 7 & FA & 5 & 3 & 6 & 3 & 5 & 3 & 25 \\
\hline 8 & GE & 8 & 7 & 8 & 6 & 5 & 4 & 38 \\
\hline 9 & NR & 6 & 5 & 4 & 5 & 3 & 4 & 27 \\
\hline 10 & $A C$ & 6 & 5 & 6 & 4 & 3 & 3 & 27 \\
\hline 11 & FA & 7 & 7 & 7 & 6 & 4 & 4 & 35 \\
\hline 12 & DS & 8 & 7 & 8 & 6 & 5 & 4 & 38 \\
\hline 13 & LF & 8 & 7 & 8 & 6 & 5 & 4 & 38 \\
\hline 14 & PD & 5 & 5 & 6 & 5 & 4 & 3 & 28 \\
\hline 15 & US & 8 & 7 & 8 & 6 & 5 & 4 & 38 \\
\hline 16 & PDM & 5 & 5 & 6 & 4 & 4 & 3 & 27 \\
\hline 17 & AJ & 6 & 5 & 5 & 4 & 4 & 3 & 27 \\
\hline 18 & $\mathrm{KR}$ & 8 & 7 & 8 & 6 & 5 & 4 & 38 \\
\hline 19 & $\mathrm{HR}$ & 5 & 6 & 7 & 4 & 3 & 3 & 28 \\
\hline 20 & AN & 8 & 7 & 8 & 6 & 5 & 4 & 38 \\
\hline
\end{tabular}

\begin{tabular}{|l|l|l|l|l|l|l|l|l|}
\hline 21 & GK & 6 & 5 & 5 & 4 & 3 & 3 & 26 \\
\hline 22 & RQ & 6 & 4 & 4 & 5 & 4 & 2 & 25 \\
\hline 23 & AY & 5 & 5 & 5 & 4 & 4 & 3 & 26 \\
\hline
\end{tabular}

Sumber: Buku Daftar Peminjaman di Perpustakaan SD Negeri Ngablak 1

\section{Prestasi Siswa kelas V}

Dari data yang diperoleh dari Nilai Akhir Semester 2 siswa kelas V SD Negeri 1 Ngablak dapat dilihat pada Tabel 3 . Peneliti melakukan penelitian analisis data dengan menghubungkan antara frekuensi kunjungan dan frekuensi peminjaman dengan urutan rangking prestasi belajar siswa. Berikut adalah pemaparan grafik dan tabel dari analisis tersebut di bawah ini.

\begin{tabular}{|c|c|c|c|c|c|c|c|c|c|c|c|c|c|c|}
\hline \multirow{2}{*}{$\begin{array}{c}\text { no } \\
\text { Absen }\end{array}$} & \multirow{2}{*}{$\begin{array}{l}\text { nama } \\
\text { Inisial }\end{array}$} & \multicolumn{11}{|c|}{ mata pelajaran } & \multirow{2}{*}{ Rata2 } & \multirow{2}{*}{$\begin{array}{l}\text { ranking } \\
\text { Prestasi }\end{array}$} \\
\hline & & PAI & PPKN & $\mathrm{BI}$ & MTK & IPA & IPS & SBK & ২JO & KJW & BTQ & $B I S$ & & \\
\hline 1 & KD & 88 & 84 & 81 & 84 & 85 & 81 & 79 & 80 & 80 & 88 & 83 & 83,00 & 7 \\
\hline 2 & DA & 86 & 83 & 79 & 78 & 79 & 74 & 79 & 89 & 77 & 82 & 74 & 80,00 & 15 \\
\hline 3 & MM & 87 & 85 & 80 & 80 & 81 & 79 & 77 & 85 & 75 & 89 & 78 & 81,45 & 12 \\
\hline 4 & ES & 85 & 80 & 79 & 74 & 76 & 74 & 78 & 79 & 75 & 79 & 72 & 77,36 & 22 \\
\hline 5 & GN & 97 & 94 & 94 & 93 & 91 & 90 & 88 & 82 & 88 & 98 & 98 & 92,09 & 1 \\
\hline 6 & FM & 86 & 83 & 77 & 74 & 77 & 74 & 77 & 82 & 75 & 80 & 71 & 77,82 & 21 \\
\hline 7 & FA & 86 & 83 & 79 & 78 & 79 & 77 & 78 & 82 & 76 & 84 & 75 & 79,73 & 8 \\
\hline 8 & GE & 93 & 90 & 91 & 92 & 88 & 87 & 83 & 84 & 85 & 95 & 89 & 88,82 & 3 \\
\hline 9 & NR & 85 & 77 & 77 & 73 & 77 & 74 & 77 & 84 & 74 & 75 & 70 & 76,64 & 23 \\
\hline 10 & $A C$ & 87 & 81 & 84 & 79 & 81 & 74 & 78 & 87 & 77 & 89 & 82 & 81,73 & 10 \\
\hline 11 & FA & 85 & 84 & 80 & 77 & 83 & 79 & 78 & 83 & 77 & 92 & 86 & 82,18 & 17 \\
\hline 12 & DS & 85 & 82 & 81 & 75 & 77 & 77 & 79 & 82 & 76 & 78 & 71 & 78,45 & 18 \\
\hline 13 & LF & 89 & 83 & 82 & 80 & 81 & 77 & 78 & 82 & 77 & 89 & 80 & 81,64 & 11 \\
\hline 14 & PD & 85 & 78 & 77 & 75 & 77 & 75 & 77 & 83 & 77 & 85 & 72 & 78,27 & 19 \\
\hline 15 & US & 96 & 88 & 89 & 88 & 77 & 87 & 82 & 84 & 84 & 93 & 94 & 87,45 & 4 \\
\hline 16 & PDM & 89 & 82 & 80 & 85 & 85 & 83 & 78 & 83 & 78 & 89 & 90 & 83,82 & 6 \\
\hline 17 & AJ & 85 & 79 & 78 & 76 & 77 & 77 & 77 & 82 & 75 & 77 & 74 & 77,91 & 20 \\
\hline 18 & $\mathrm{KR}$ & 88 & 82 & 82 & 82 & 83 & 78 & 78 & 81 & 77 & 84 & 85 & 81,82 & 9 \\
\hline 19 & $\mathrm{HR}$ & 94 & 88 & 90 & 90 & 85 & 84 & 81 & 90 & 82 & 90 & 81 & 86,82 & 5 \\
\hline 20 & AN & 96 & 93 & 93 & 92 & 90 & 88 & 82 & 83 & 86 & 92 & 91 & 89,64 & 2 \\
\hline 21 & GK & 85 & 80 & 81 & 80 & 79 & 78 & 77 & 85 & 77 & 78 & 78 & 79,82 & 16 \\
\hline 22 & $\mathrm{RQ}$ & 87 & 81 & 82 & 80 & 82 & 82 & 82 & 81 & 77 & 78 & 80 & 81,09 & 13 \\
\hline 23 & AY & 89 & 82 & 78 & 77 & 84 & 75 & 77 & 88 & 75 & 80 & 77 & 80,18 & 14 \\
\hline
\end{tabular}

Sumber : Rapot Akhir Semester SD Negeri Ngablak 1, Kurikulum 13 
Penyajian Data Pada Grafik 1 digambarkan bahwa rangking prestasi terbaik memiliki jumlah frekuensi kunjungan dan peminjaman yang tinggi, namun terdapat beberapa siswa yang frekuensi kunjungan dan peminjaman tinggi tetapi mendapatkan rangking prestasi di bawah frekuensi kunjungan dan peminjaman lebih rendah. Dalam bentuk Tabel 4 menunjukan bahwa peringkat prestasi siswa yang mendapat rangking 1 (satu) diduduki oleh siswa GN dengan hasil nilai rata rata 92,09 . Hal tersebut didukung dengan frekuensi kunjungan sebanyak 102 kali dan peminjaman di perpustakaan sebanyak 38 kali. Peringkat selanjutnya juga memiliki frekuensi yang sama yaitu 10 kali kunjungan dan 38 kali peminjaman yaitu $A N, G E$, US, dengan rangking yang berurutan yaitu rangking 2, 3, dan 4. Sedangkan untuk HR dapat menduduki prestasi peringkat 5 meskipun frekuensi kunjungan 72 kali dan peminjaman 28 kali, frekuensi tersebut lebih rendah dari pada siswa yang frekuensi kunjungan dan peminjaman ke perpustakaannya lebih tinggi seperti siswa KR yang frekuensi kunjungannya 100 kali dan peminjaman 38 kali meski siswa tersebut hanya menduduki rangking 9. Hasil prestasi terendah adalah siswa NR dengan nilai rata - rata 76,64 dengan frekuensi kunjungan ke perpustakaan 67 kali dan peminjaman 27 kali. Frekuensi tersebut lebih tinggi dari pada siswa DA yang frekuensi kunjungan ke perpustakaan 64 kali dan peminjaman buku 27 kali namun rangking yang didapat siswa DA yaitu rangking 15 dengan nilai rata - rata 80,00 .

Grafik 1. Pengunjung dan Peminjaman Berdasarkan Prestasi Belajar Siswa SD Negeri Ngablak 1

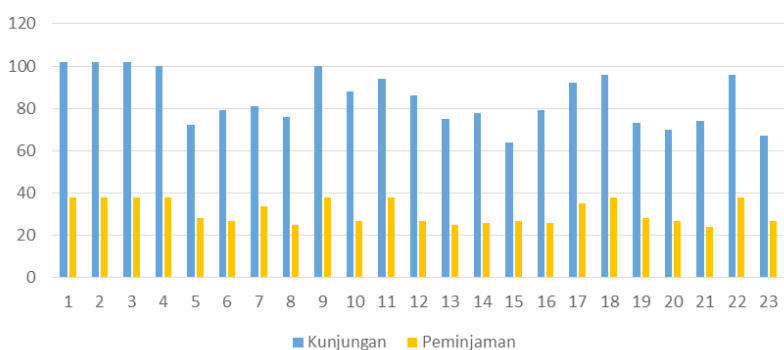

Dalam Kalender Semester 2 tahun 2019 terdapat 123 kali hari efektif perpustakaan dalam pelayanan kepada siswa sesuai jadwal yang ditetapkan, siswa kelas $\mathrm{V}$ dapat meminjam buku maksimal 38 kali di perpustakaan sekolah. GN sebagai peraih rangking terbaik pada tes akhir semester 2 tahun 2019 memanfaatkan layanan perpustakaan dengan persentase 82,93 \% hari efektif dalam berkunjung dan persentase $100 \%$ peminjaman buku di Perpustakaan.

Tabel 5. Rekapitulasi Pengunjung dan Peminjaman Buku Perpustakaan Berdasarkan Rangking Prestasi Belajar Siswa Kelas V SD Negeri Ngablak 1

Tes Akhir Semester 2 Tahun 2019

\begin{tabular}{|c|c|c|c|c|c|}
\hline $\begin{array}{l}\text { Rangking/ } \\
\text { Prestasi }\end{array}$ & $\begin{array}{l}\text { No } \\
\text { urut }\end{array}$ & $\begin{array}{l}\text { Nama } \\
\text { Inisial }\end{array}$ & $\begin{array}{l}\text { Pengun- } \\
\text { jungan }\end{array}$ & $\begin{array}{l}\text { Peminja- } \\
\text { man }\end{array}$ & $\begin{array}{c}\text { Nilai Rata - } \\
\text { Rata }\end{array}$ \\
\hline 1 & 5 & GN & 102 & 38 & 92,09 \\
\hline 2 & 20 & AN & 102 & 38 & 89,64 \\
\hline 3 & 8 & GE & 102 & 38 & 88,82 \\
\hline 4 & 15 & US & 100 & 38 & 87,45 \\
\hline 5 & 19 & HR & 72 & 28 & 86,82 \\
\hline 6 & 16 & PDM & 79 & 27 & 83,82 \\
\hline 7 & 1 & $\mathrm{KD}$ & 81 & 34 & 83,00 \\
\hline 8 & 11 & FA & 92 & 35 & 82,18 \\
\hline 9 & 18 & $\mathrm{KR}$ & 100 & 38 & 81,82 \\
\hline 10 & 10 & $A C$ & 88 & 27 & 81,73 \\
\hline 11 & 13 & LF & 94 & 38 & 81,64 \\
\hline 12 & 3 & MM & 86 & 27 & 81,45 \\
\hline 13 & 22 & $\mathrm{RQ}$ & 75 & 25 & 81,09 \\
\hline 14 & 23 & AY & 78 & 26 & 80,18 \\
\hline 15 & 2 & DA & 64 & 27 & 80,00 \\
\hline 16 & 21 & GK & 79 & 26 & 79,82 \\
\hline 17 & 7 & FA & 76 & 25 & 79,73 \\
\hline 18 & 12 & DS & 96 & 38 & 78,45 \\
\hline 19 & 14 & PD & 73 & 28 & 78,27 \\
\hline 20 & 17 & AJ & 70 & 27 & 77,91 \\
\hline 21 & 6 & FM & 74 & 24 & 77,82 \\
\hline 22 & 4 & ES & 96 & 38 & 77,36 \\
\hline 23 & 9 & NR & 67 & 27 & 76,64 \\
\hline \multicolumn{3}{|c|}{ Jumlah Total } & 1946 & 717 & \\
\hline
\end{tabular}

Analisis Data 7 November 2019 
Namun terdapat pula siswa yaitu HR dengan rangking 5 pada tes akhir semester 2 memanfaatkan layanan perpustakaan dengan persentase 58,53\% kunjungan ke perpustakaan dan persentase 73,68 $\%$ Peminjaman buku.

Dari analisis tersebut maka ditemukan bahwa terdapat perbedaan yang kurang signifikan antara siswa yang memanfaatkan perpustakaan lebih banyak dengan yang sedikit, karena terdapat siswa yang memanfaatkan perpustakaan lebih banyak namun prestasi belajar dari hasil tes akhir semester 2 tahun 2019 lebih rendah daripada yang memanfaatkan perpustakaan lebih sedikit. Meski begitu dari data diatas mayoritas siswa yang memanfaatkan perpustakaan lebih sering akan mendapat nilai prestasi yang lebih baik daripada yang memanfaatkan perpustakaan lebih sedikit. Maka terdapat hubungan positif antara pemanfaatan perpustakaan terdapat prestasi belajar siswa kelas V SD Negeri Ngablak 1 Kecamatan Ngablak Kabupaten Magelang Tahun 2019.

\section{E. PENUTUP}

\section{Simpulan}

Pada semester 2 kelas V SD Negeri Ngablak 1 melakukan kunjungan ke perpustakaan sekolah sebanyak 1946 kali dengan waktu peminjaman buku sebanyak 717 kali. Frekuensi berkunjung terbanyak ditempati oleh GN, AN, GE, US yang secara berurutan menempati prestasi rangking 1, 2, 3 dan 4 dalam Tes akhir semester 2 . Namun terdapat juga siswa dengan frekuensi berkunjung yang lebih rendah namun mendapat prestasi yang lebih tinggi yaitu HR dan FA dari pada yang frekuensi lebih tinggi yaitu KR, RF, DF dan ES. Pengaruh frekuensi berkunjung dan meminjam di perpustakaan berpengaruh pada prestasi belajar Tes Akhir semester 2 tahun 2019 di sebagian besar siswa kelas V SD Negeri Ngablak 1. Siswa dengan frekuensi kunjungan dan peminjaman ke perpustakaan lebih sedikit juga sebagian memiliki prestasi yang lebih rendah.

\section{Saran}

Selain mengikuti belajar di dalam kelas, siswa diharapkan juga belajar mandiri diluar jam pelajaran yaitu dengan berkunjung dan meminjam di perpustakaan. Dengan memanfaatkan perpustakaan, maka pengetahuan siswa akan lebih banyak diterima dan prestasi siswa akan lebih baik. Kepada pihak sekolah dimohon untuk meningkatkan pelayanan dan koleksi dari buku - buku di perpustakaan, dan juga kepada guru dapat mencari faktor lain yang menyebabkan kenapa kepada beberapa siswa yang frekuensi berkunjung dan meminjam buku lebih banyak masih mendapat rangking yang lebih rendah.

Penulis menyadari bahwa karya ilmiah ini banyak sekali kekurangan, maka dengan senang hati dan terbuka penulis memohon untuk kritik dan saran bagi pembaca. Semoga karya ilmiah ini dapat bermanfaat, khususnya dibidang perpustakaan.

\section{DAFTAR PUSTAKA}

Bafadal, I. (2006). Pengelolaan Perpustakaan Sekolah. Bumi Aksara.

Bernacki, L, M., Greene, A, J., \& Crompton, H. (2020). Mobile technology, learning, and achievement: Advances in understanding and measuring the role of mobile technology in education. Contemporary Educational Psychology, 60.

Gulo, W. (2002). Metodologi Penelitian. PT Gramedia Widiasarana Indonesia.

Hartinah, S. (2013). Metode Penelitian Perpustakaan. Universitas Terbuka.

R, D. G., Wang, C., \& Berthelsen, D. (2016). Early schoolbased parent involvement, children's self-regulated learning and academic achievement: An Australian longitudinal study. Early Childhood Research Quarterly, 36(3), 168-177. 
